\title{
Unification and/or Brexit? Nationalism(s) and the Good Friday Agreement
}

Sarah Ritt*

\begin{abstract}
With Brexit being an ongoing issue for all of the European Union, one of the key issues in the negotiations is how to treat Northern Ireland, which is still divided on Brexit ideologically, even 20 years after the official peace treaty (the Good Friday Agreement), which - at least legally - put an end to armed conflict in the area. This paper will look at how in 2018, the $20^{\text {th }}$ anniversary of the Good Friday Agreement, the two prevalent opposing nationalisms - unionism and republicanism - are represented in a selection of widely-read newspapers in Northern Ireland. Using Spitzmüller and Warnke's DIMEAN model, the paper will look at how - given the different ideological backgrounds of the newspapers themselves - these publications treat the anniversary and give a voice to the different parties involved (or abstain from doing so) and whether or not they make explicit links to the Brexit negotiations and the question, whether Northern Ireland is to continue as a part of the United Kingdom, the European Union or a separate customs union solution, in order to both keep the terms of the Good Friday Agreement and deal with two broadly different civic realities, brought about by opposing notions of nationalism.
\end{abstract}

Key words: Brexit, Northern Ireland, DIMEAN, newspaper, CDA, discourse analysis

\footnotetext{
* University of Vienna; sarah.m.ritt@gmail.com
} 


\section{Introduction}

One of the key points in the discussion around Brexit - the United Kingdom leaving the European Union - is how to deal with Northern Ireland, especially in terms of the free movement of goods, services, and people, and the border to the Republic of Ireland. All of these issues do not only arise because of the shared border to the Republic, an EU member state, but also because the Good Friday Agreement, which formally concluded the Northern Ireland conflict, included freedom of movement of people between the North and the Republic. Also, the region of the Irish island which belongs to the United Kingdom heavily profits, if not to say is dependent on, the Peace Fonds of the European Union.

This paper will examine said Good Friday Agreement - which was the formal beginning of the decommission of paramilitary forces in Northern Ireland and the saw the establishment of a local government - and the different types of nationalisms that could be observed in local news outlets around its 20th anniversary. Good Friday 2018 marked the 20th anniversary of the Agreement (from here on: GFA), and while this occasion sparked different nationalistic sentiments (the different types of nationalisms in Northern Ireland will be discussed below), Brexit adds a new dimension to the portrayal of the GFA and the nationalistic tendencies displayed within the field of domestic politics in Northern Ireland in general.

Very broadly speaking, there are two different socio-political groups, that display very different views on nationalism: Nationalists see themselves as Irish, they want a united Ireland that encompasses the whole island and they see the fact that Northern Ireland is British as a state of oppression. Some of them speak Irish Gaelic and the majority of them can be considered Roman Catholic. Almost half of the population ( $48 \%$, according to the 2011 NI census, cf. NISRA 2011, 3) included British as their identity, they are content with living in a part of the United Kingdom, although they are not necessarily pro Brexit. These people can be considered closer to the Anglican or Presbyterian faith. Both sides have their political parties (most famously Sinn Fein and the Democratic Unionist Party) and paramilitary, mafia-like organisations (most famously the IRA and the UDA). This very basic distinction is by no means intended to draw further divisions or paint the northern Irish situation as black and white and stuck in a violent past, but it is the basis for a proper understanding of not only current affairs regarding this area, but more specifically the Northern Irish media landscape. 


\section{Newspapers - Authority, Modality, and Reach}

In the $21^{\text {st }}$ century, newspapers may not seem like the medium of choice to investigate sentiments such as nationalism, as it imposes the authority of the author on the reader and, at least in the print version of this medium, there is no opportunity for the audience to directly engage with what they just read. On the other hand, all the news outlets used as sources here have an online presence, which does allow readers to either comment directly below the article or, with the help of a 'sharing' function, transfer what they have read to other platforms that have commentary functions and possibly a wider audience (Twitter, Facebook etc.). This switching of content from printing to online publishing also allows for a more international audience and, if there is no paywall, its is even free of charge, in contrast to the print version. What applies to both on- and offline news articles is the fact that they are multimodal: Text is almost always accompanied by a picture or even a video.

At a time when there is a plethora of non-journalistic outlets and 'alternative facts' on the internet, the initial authority of the journalist of a large outlet is by no means a given.

\section{Data}

The articles under investigation stem from four different newspapers from different countries and different political orientations. The four newspapers are the following:

- Belfast Telegraph (a unionist newspaper from Belfast)

- The NewsLetter (a unionist newspaper from Northern Ireland)

- The Guardian (from England)

- The Irish Times (from Ireland)

The articles used were published in a time span of two weeks before and after Good Friday 2018, which fell on the 30 March that year. Only articles that included the words 'Good Friday agreement' or 'Belfast Agreement' (see 'Methodology') in the title were used, as the analysed articles needed to be as relevant to the key terms as possible. From a standpoint rooted in Pragmatics

[A] good headline is one which helps the reader deduce the maximal amount of contextual effects for the minimal amount of processing effort. Then, they guide individual readers to those specific stories which would be worth their while to read in the full version. Thus, the reading patterns manifested by newspaper readers are exactly what we should expect: Readers regularly scan the headlines, and only occasionally stop to read the actual 
story. As relevance-optimizers and relevance-based selection-devices, headlines function as negotiators between stories and readers. As we have seen, producing the appropriate headline for a story is a complex task exactly because the headline is neither a semantic summary of the story nor a pragmatic attracting-device for the reader, but a communicative device whose function is to produce the optimal level of affinity between the content of the story and the reader's context of interpretation, in order to render the story optimally relevant for the reader. (Dor 2005, 720-721)

Therefore, a communicative device using exactly the terms this paper wants to investigate will be the most efficient way to go forward. What might be called a downside is that it drastically reduces the number of items in the corpus to 14 articles in the Belfast Telegraph, 4 in the Irish Times, 1 in the Guardian and none in The NewsLetter. 


\section{Methodology}

In addition to using the words 'Nationalism' and 'Brexit' both as search terms within the articles as well as looking for them as (maybe not explicitly mentioned) concepts, two further elements will feed into this framework: The so-called DIMEAN model (Spitzmüller and Warnke 2011) and the notion of the discourse-historical approach as coined by Ruth Wodak (Wodak and Meyer 2016).

Tabelle 3.15r Layout der diskurslinguistischen Mehr-Ebenen-Analyse (DIMEAN)

\begin{tabular}{|c|c|c|c|}
\hline \multirow{7}{*}{$\begin{array}{l}\text { Transtextuelle } \\
\text { Ebene }\end{array}$} & \multirow{7}{*}{$\begin{array}{l}\text { Diskurs- } \\
\text { orientierte } \\
\text { Analyse }\end{array}$} & \multicolumn{2}{|l|}{$[\ldots]$} \\
\hline & & \multicolumn{2}{|c|}{ Idealogien, Gousernementalitidt, Mentalisititen } \\
\hline & & \multicolumn{2}{|l|}{ Historizität } \\
\hline & & \multicolumn{2}{|c|}{ Indexikalische Ordnungen, Sozialbymbolik } \\
\hline & & \multicolumn{2}{|c|}{ Diskunsemantische Grundffguren } \\
\hline & & \multicolumn{2}{|l|}{ Findme, Topoi } \\
\hline & & \multicolumn{2}{|l|}{ Intertextualität } \\
\hline \multirow{3}{*}{ Akteure } & \multirow{3}{*}{ 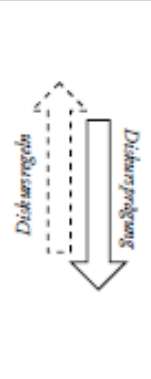 } & Medialităt & $\begin{array}{l}-[\ldots] \\
- \text { Handlungsmuster } \\
\text { - Kommunilkationsformen } \\
\text { - Medium } \\
\end{array}$ \\
\hline & & Diskurspositionen & 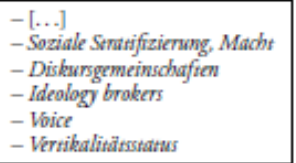 \\
\hline & & Interaktionsrollen & $\begin{array}{l}\text { - [...] } \\
\text { - Resipientenrollen } \\
\text { - Produzentenrollen } \\
\end{array}$ \\
\hline \multirow{6}{*}{$\begin{array}{l}\text { Intratextuelle } \\
\text { Ebene }\end{array}$} & \multirow{3}{*}{$\begin{array}{l}\text { Textorientierte } \\
\text { Analyse }\end{array}$} & $\begin{array}{l}\text { Visuelle } \\
\text { Textstruktur }\end{array}$ & $\begin{array}{l}\text { - [...] } \\
\text { - Tex-Bild-Beziehungen } \\
\text { - Tjpognatphie } \\
\text { - Materialititit } \\
\end{array}$ \\
\hline & & $\begin{array}{l}\text { Makrostruktur: } \\
\text { Textthema(ta) }\end{array}$ & \multirow{2}{*}{$\begin{array}{l}\text { - [...] } \\
\text { - Metaphernfalder } \\
\text { - Lexikalische Felder } \\
\text { - Isotopie- und Oppositionslinien } \\
\text { - Themenentfaltung } \\
\text { - Texufunktionen } \\
\text { - Textsorte }\end{array}$} \\
\hline & & $\begin{array}{l}\text { Mesostruktur: } \\
\text { Themen in } \\
\text { Textteilen }\end{array}$ & \\
\hline & $\begin{array}{l}\text { Propositions- } \\
\text { orientierte } \\
\text { Analyse }\end{array}$ & $\begin{array}{l}\text { Textuelle } \\
\text { Mikrostruktur: } \\
\text { Propositionen }\end{array}$ & $\begin{array}{l}\text { - [...] } \\
\text { - Syntakrische Muster } \\
\text { - Rherorische Tropen und Figuren } \\
\text { - Metaphernlexeme } \\
\text { - Deontische Bedewsung } \\
\text { - Implibasuren, Präsuppositionen } \\
\text { - Sprechabte }\end{array}$ \\
\hline & \multirow{2}{*}{$\begin{array}{l}\text { Wortorientierte } \\
\text { Analyse }\end{array}$} & Mehrwort-Einheiten & \multirow{2}{*}{$\begin{array}{l}\text { - [...] } \\
\text { - Obbasionalismen } \\
\text { - Schlagwönter } \\
\text { - Schlüsselvörter } \\
\text { - Nomind continuativat } \\
\text { - Nomind appellativa, } \\
\text { Nomind collectivat } \\
\text { - Nomina propria } \\
\end{array}$} \\
\hline & & Einwort-Einheiten & \\
\hline
\end{tabular}

Figure 1: DIMEAN (Spitzmüller and Warnke 2011, 201)

Although DIMEAN was never meant to be a strict model, but rather an illustration in the authors' joint book, it has been used as a guideline apparently because of its transparent and clear-cut nature: It visualises nicely what makes an individual text and what 
can be found when moving further to the trans-textual level and, this is the main point of it, the two authors assign a very special meaning to the actors, not only the authors, which is crucial not only for this paper but for communication studies as such. In this paper, the model will not be used as a checklist which needs to be followed item by item, but there will be an emphasis on the following aspects:

As an ideological guide, the Discourse Historical Approach (DHA) will be used: Found under the Critical Discourse Studies umbrella, DHA promotes transdisciplinarity and a problem-oriented approach. The problem in this specific case (in a consideration of Brexit) would be the influence of two very different strands of nationalism on the media coverage of what is effectively a peace treaty. By viewing communication as 'multifaceted phenomena in our society', this approach opens the way for changing the angle of analysis and focusing not only on the author, not only on the recipient and not only on the content of text, but on a combination of all these (f)actors.

DHA promotes three dimensions to an analysis: Identifying contents/topics of a discourse, finding out discursive strategies and, finally, investigating their linguistic means and linguistic realisations. This is especially useful in a political context, as the discursive strategies might not be as clear as they seem at first glance. Like the DIMEAN-model, the focus with DHA is on intertextuality and, additionally, on interdiscursivity. The most appealing notion of this method is that it requires its users to adopt an interdisciplinary focus and to take current events and research from other disciplines into account.

Drawing from these two methodological strands, the following questions were formulated, always with the keywords 'nationalism' and 'Brexit' in mind:

- What ideologies regarding nationalism are shared across newspapers? (Taken from DIMEAN's trans-textual plane)

- Who gets a voice? (Who is given a voice by the author?) Who has the power to dominate the discourse about nationalism through the medium of a newspaper article? (Taken from DIMEAN's 'actors' plane)

- How are the communicative strategies regarding this topic different in different newspapers?

What needs to be considered is that the GFA is also called the Belfast Agreement, as the treaty is referred to either by the place or the date it was signed. The usage of either name can have several reasons: Not wanting to use a religious holiday in the name or quite the opposite, highlighting just that. Also mentioning the place name makes it clear that a treaty concerning the area was signed in the area, not centralised from London, which could be interpreted as an act of colonial domination. Both the terms 'Belfast 
Agreement' and 'Good Friday Agreement' were used as search terms for the collection of data for this paper.

\section{Results}

\section{Belfast Telegraph}

The Belfast Telegraph has by far the most articles that have 'Belfast Agreement' or 'Good Friday Agreement' in their titles within a two-week timespan surrounding the treaty's anniversary. 9 of these can be found within a separate 'Good Friday Agreement' category, 1 in 'Films', 1 in 'Featured' and the remaining 3 in 'Politics - Northern Ireland'. Featuring political figures from across the spectrum (the then Brexit Secretary David Davis, the SDLP deputy leader Nicola Mallon, PUP leader Billy Hutchinson, the former Deputy First Minister Seamus Mallon) and even incorporating an artist (the Downpatrick-born comedian Patrick Kielty), this newspaper has the most diverse approach to the topic, given the set search terms. Broadening the topic to the cultural section of news reporting, there seems to be an attempt to make the discussion about the agreement a more holistic one, not limiting it to politics. Nevertheless, their outlook is not inherently positive, as shown in the following example, a (partly indirect) quote by the PUP leader William 'Billy' Hutchinson: "Hutchinson stressed that Sinn Fein and the DUP needed to find a way of breaking the deadlock at Stormont. He also said that the death of former PUP leader David Ervine from a heart attack 11 years ago at the age of 53 had been 'a blow to loyalism'. He said that if his friend, who 'wanted to change the world', was alive today he would be 'totally frustrated'” (Weir 2018, paragraphs 6-8).

\section{The NewsLetter}

In contrast to the online presence of the other newspapers, The NewsLetter does not have a search function as such on its page, but a search for the respective key words in the set time frame could be conducted easily with the help of the Google search function. After changing the parameters to only having the treaty's name in the title, there were no results left for this newspaper. Linking this back to the pragmatic functions of headlines, it can be assumed that the audience of the online version of the newspaper does either not have the need for pragmatic markers of that much strength or, in combination with the missing search tool, that the titles are not optimised for a search function and, when purchased in print, the articles reach their audience without the 'agreement' in the title, therefore making this an issue of modality. 


\section{The Guardian}

The only article that fit the set search criteria is an opinion piece, which tries to convey an outsider's perspective, but only explicitly mentions pro-British politicians (Theresa May, Ian Paisley and Arlene Foster). By mentioning that the agreement has two names, the author tries to show cross-community awareness, and he also explains how Brexit and the possibility of a hard border will change the North, but the 'failure' of Northern Ireland, as he calls it, to him is not only Brexit's fault. Nevertheless, the author concludes with the following paragraph:

Making a success of the agreement of two decades ago requires knowledge, attitude and will on all sides. Britain displays none of these things with the requisite consistency any more. The result is a huge missed opportunity. The people of these islands have rarely been more convergent or neighbourly than they have been over the past 20 years. But it is hard to believe that the same will be said after the next 20. (Kettle 2018, np)

\section{The Irish Times}

Remarkably, The Irish Times exclusively used the term 'Belfast Agreement' in its respective titles. One of the search results is actually a video (a very efficient use of the online format of the newspaper medium) which features the former leader of the Alliance Party, a party which refuses to be categorised by the unionist/republican divide. An article published a day prior to that video clip featured the former leader of the SDLP, the local Social Democratic Party and one from a week after the signing of the Agreement (5 April) featured the then Northern Ireland Secretary of State, Marjorie "Mo" Mowlam. The fourth article is concerned with policing and how the police force has changed in the last 20 years. Looking at three very important negotiators of the original agreement, but completely sparing testimonies by the two main parties, Sinn Fein and the DUP, might target an audience that is already familiar with what the GFA entails and who just want to find different angles linked to this discourse. One example for this would be the following paragraph:

The most challenging difficulty externally is the euphemistically termed "dealing with the past". There is an organisational legacy to conflict, just as there is a political one. The PSNI has still to grasp this nettle fully - both in terms of its own role and the role of others. (Murphy 2018, paragraph 17)

The difficulties and the past of the organisation cannot be fully explained by one single article, so there is a certain amount of historical knowledge expected from the reader. 


\section{Conclusion}

What can be said for all of the articles under examination is that, surprisingly enough, with one exception (that being a Belfast Telegraph poll, a format that is highly dependent on its readers' interaction with it), there was nothing that fit the pragmatically well-chosen search criteria and featured 'ordinary people' or victims' rights campaigners. Nationalism (of whatever sort) was never explicitly evoked, although to informed readers it should be clear which stance the interviewed politicians take: The fact that two clashing nationalisms, however moderate or extreme they might be, expressed by individuals, exist, is not questioned. Looking at it from the Republic, the commentator of The Irish Times even tried to downplay the effects of Brexit in case of a hard border, while his colleagues seem to mostly focus on a historical recapitulation of the events than on using the anniversary to make predictions on how deal with Brexit, how to secure the comparatively young peace, or how to not fall for an unhealthy dose of nationalism in the first place, something which has been done already, proven by the fact that there even is a thing such as Brexit to begin with.

\section{References}

"Bill Clinton to Visit Northern Ireland to Mark Good Friday Agreement Anniversary." Belfast Telegraph, 29 March 2018. Accessed 12 September 2019. https://www.belfasttelegraph.co.uk/ news/good-friday-agreement/bill-clinton-to-visit-northern-ireland-to-mark-good-friday-agre ement-anniversary-36757774.html.

“Census 2011: Key Statistics for Northern Ireland.” Statistics Bulletin. Northern Ireland Statistics Research Agency (NISRA). 11 December 2012. Accessed 12 September 2019. https:// www.nisra.gov.uk/sites/nisra.gov.uk/files/publications/2011-census-results-key-statistics-sta tistics-bulletin-11-december-2012.pdf.

Cross, Gareth. 2018. “SDLP Query Hume’s Omission in BBC’s Good Friday Agreement Coverage.” Belfast Telegraph, 30 March 2018. Accessed 12 September 2019. https://www.belfast telegraph.co.uk/news/good-friday-agreement/sdlp-query-humes-omission-in-bbcs-good-fri day-agreement-coverage-36759919.html.

Curran, Ed. 2018. 29 March 2018. “The Good Friday Agreement Brought Much-Needed Normality... But the Unresolved Question of Identity Still Haunts This Island.” Belfast Telegraph, 29 March 2018. Accessed 12 September 2019. https://www.belfasttelegraph.co.uk/ news/good-friday-agreement/the-good-friday-agreement-brought-muchneeded-normalitybut-the-unresolved-question-of-identity-still-haunts-this-island-36754298.html.

Dalton, Maria. 2018. "With the Toss of a Wig! Mo Mowlam and the Belfast Agreement." The Irish Times, 5 April 2018. Accessed 12 September 2019. https://www.irishtimes.com/culture/ books/with-the-toss-of-a-wig-mo-mowlam-and-the-belfast-agreement-1.3451409. 
Dixon, Paul. 2018. “The Truth About the Good Friday Agreement Is That, If It Wasn't for Deliberate Deceptions, There Would Be No Peace Process Here.” Belfast Telegraph, 28 March 2018. Accessed 12 September 2019. https://www.belfasttelegraph.co.uk/news/good-fridayagreement/the-truth-about-the-good-friday-agreement-is-that-if-it-wasnt-for-deliberate-decep tions-there-would-be-no-peace-process-here-36750388.html.

Editor's Viewpoint. 2018. “20 Years After Agreement, Museum’s Troubles Exhibition Shows How Far We've Come, And How Far We Have to Go.” Belfast Telegraph, 31 March 2018. Accessed 12 September 2019. https://www.belfasttelegraph.co.uk/news/good-friday-agreement/ 20-years-after-agreement-museums-troubles-exhibition-shows-how-far-weve-come-and-howfar-we-have-to-go-36760766.html.

“Good Friday Agreement: Share Your Views 20 Years On.” Belfast Telegraph, 5 April 2018. Accessed 12 September 2019. https://www.belfasttelegraph.co.uk/news/good-friday-agreement/ good-friday-agreement-share-your-views-20-years-on-36778083.html.

"Ivan Little Pays a Visit to a Thought-Provoking New Exhibition at the Ulster Museum, Launched to Mark the 20th Anniversary of the Good Friday Agreement.” Belfast Telegraph, 30 March 2018. Accessed 12 September 2019. https://www.belfasttelegraph.co.uk/life/features/ivanlittle-pays-a-visit-to-a-thoughtprovoking-new-exhibition-at-the-ulster-museum-launched-tomark-the-20th-anniversary-of-the-good-friday-agreement-36758206.html.

Kettle, Martin. 2018. "The Good Friday Agreement is 20 - and Britain Can't Afford to Forget It.” The Guardian, 5 April 2018. Accessed 12 September 2019. https://www.theguardian. com/commentisfree/2018/apr/05/good-friday-agreement-20-britain-ireland-peace-process.

McClements, Freya. 2018. "Mark Durkan on Belfast Agreement: 'What Are You Going to Replace It With??.” The Irish Times, 30 March 2018. Accessed 12 September 2019. https://www. irishtimes.com/news/ireland/irish-news/mark-durkan-on-belfast-agreement-what-are-yougoing-to-replace-it-with-1.3444439.

McHugh, Michael. 2018. “Good Friday Agreement's Tenets Now Used Globally.” Belfast Telegraph, 6 April 2018. Accessed 12 September 2019. https://www.belfasttelegraph.co.uk/news/ northern-ireland/good-friday-agreements-tenets-now-used-globally-36779465.html.

Murphy, Joanne. 2018. “Belfast Agreement, 20 Years On: 'It's Difficult to Be Optimistic'.” The Irish Times, 31 March 2018. Accessed 12 September 2019. https://www.irishtimes.com/news/ politics/the-agreement/belfast-agreement-20-years-on-it-s-difficult-to-be-optimistic-1.3447012.

Murphy, Joanne. 2018. "Policing in Northern Ireland Since the Belfast Agreement." The Irish Times, 30 March 2018. Accessed 12 September 2019. https://www.irishtimes.com/news/crimeand-law/policing-in-northern-ireland-since-the-belfast-agreement-1.3445634.

O’Boyle, Claire. 2018. “Good Friday Agreement: Chance to View the Hands that Made History.” Belfast Telegraph, 4 April 2018. Accessed 12 September 2019. https://www.belfasttele graph.co.uk/news/good-friday-agreement/good-friday-agreement-chance-to-view-the-handsthat-made-history-36772419.html.

“Patrick Kielty Good Friday Agreement Documentary Impresses Viewers.” Belfast Telegraph, 4 April 2018. Accessed 12 September 2019. https://www.belfasttelegraph.co.uk/entertainment/ film-tv/news/patrick-kielty-good-friday-agreement-documentary-impresses-viewers-36776058.html. 
“Poll: Was the Good Friday Agreement a Success or Failure?” Belfast Telegraph, 11 April 2018. Accessed 12 September 2019. https://www.belfasttelegraph.co.uk/news/good-friday-agree ment/poll-was-the-good-friday-agreement-a-success-or-failure-36793003.html.

"SDLP host Good Friday Agreement Anniversary Dinner." Belfast Telegraph, 6 April 2018. Accessed 12 September 2019. https://www.belfasttelegraph.co.uk/news/northern-ireland/sdlphost-good-friday-agreement-anniversary-dinner-36782490.html.

Smith, Lydia. 2018. "We Will Defend the Belfast Agreement After EU Exit, Says David Davis." Belfast Telegraph, 26 March 2018. Accessed 12 September 2019. https://www.belfasttelegraph. co.uk/news/northern-ireland/we-will-defend-the-belfast-agreement-after-eu-exit-says-daviddavis-36742597.html.

Spitzmüller, Jürgen and Warnke, Ingo. 2011. Diskurslinguistik: Eine Einführung in Theorien und Methoden der Transtextuellen Sprachanalyse. Berlin and Boston: De Gruyter Mouton.

Staff Reporter. 2018. "Don't Throw Away the Gains of Good Friday Agreement: Mallon." Belfast Telegraph, 31 March 2018. Accessed 12 September 2019. https://www.belfasttelegraph. co.uk/news/good-friday-agreement/dont-throw-away-the-gains-of-good-friday-agreementmallon-36761001.html.

Weir, Michelle. 2018. "Northern Ireland Has Gone Backwards in Since Good Friday Agreement, Says Hutchinson.” Belfast Telegraph, 4 April 2018. Accessed 12 September 2019. https://www.belfasttelegraph.co.uk/news/good-friday-agreement/northern-ireland-has-gonebackwards-in-since-good-friday-agreement-says-hutchinson-36771379.html.

Wodak, Ruth and Michael Meyer, eds. 2016. Methods of Critical Discourse Studies. Los Angeles: Sage. 